\title{
Resistance Evaluation of Some Rice Cultivars by Feeding Activity of Brown Planthopper Population in Java
}

\author{
Willing Bagariang*, Wayan Murdita, Suwarman, Ahmad Imroni \\ Pest Forecasting Institute, Directorate General of Food Crop, Ministry of Agriculture \\ *Corresponding author. Email: willingbagariang@gmail.com
}

\begin{abstract}
The Brown Planthopper (BPH) attack reduced the rice yield in rice producer countries of Asia. In Indonesia, the area of BPH infestation frequently fluctuated over the year. BPH directly caused hopper burn and it is also the vector of rice virus. This study aimed to evaluate the resistance of some rice cultivars against several BPH populations in Java. Three BPH populations collected from Karawang (West Java), Pekalongan (Central Java) and Kendal (Central Java) were used in this study. The rice resistance was evaluated by conducting honeydew test. There were eight rice cultivars tested i.e Sembada 168, Ciherang, Inpari 32, Inpari 33, IR 64, TN1, Ratu Heenati and PTB 33 with five replications. A number of 200 female adults (five females per plot) were starved for 2 hours before inserting to pot containing one seedling. The BPH adults were allowed to feed 40-day-old plants for 48 hours. The area of honeydew spots was measured using software of Image J. We used analysis of variance (ANOVA) and cluster analysis with ward method and similarity index of Euclidean distance to analyze the rice resistance to BPH. The study indicated three groups of rice resistance level. The cultivars Sembada 168 and TN1 were grouped as susceptible, cultivars Ciherang, Inpari 32, Inpari 33 and IR 64 were grouped as moderately resistant, and cultivars PTB 33 and Ratu Heenati were grouped as strongly resistant to BPH populations of Java.
\end{abstract}

Keywords: honeydew, java, Nilaparvata lugens, resistance, rice

\section{Introduction}

Most of Asia countries planted rice as their main food crop. The rice production is mostly influenced by biotic and abiotic factors. The biotic factor causes yield loss around $52 \%$ in rice production and the attack of pests cause $21 \%$ production loss $[1,2]$. Brown planthopper (BPH) is known as the economic important pest of rice and its infestation on rice caused severe yield loss in Asia. BPH is a sap feeder and severe infestation of BPH causes plant to dry up which is called "hopper burn" [3]. Indirectly, BPH is an effective vector of two important rice viruses namely rice grassy stunt virus [4] and rice ragged stunt virus [5].

The BPH usually resides on the rice stalk and sucks the phloem sap using its stylet. The BPH excretes honeydew which consists of sugars and amino acids [6]. The amount of honeydew excreted by BPH can be used as an indicator of the rice resistance level [7]. Study of rice resistance to BPH can be done by the method of preference or non preference, antibiosis, honeydew experiment or tolerance. The quantitative evaluation of rice resistance against BPH usually measure the amount of honeydew production [8]. The study of rice resistance using honeydew excreted by BPH has been carried out by many researchers [9-11]. One of the effective methods to control the BPH damage on rice is to develop the rice resistant cultivars. Rice cultivars with resistance genes such as Mudgo, ASD7, Ratu Heenati and Babawee have been developed as parents for rice resistant breeding [12, 13]. Although rice cultivars with these resistance genes have been developed, the brown planthopper is still able to adapt and break the resistance genes [14-16]. 
Indonesia is one of the largest rice producers in Asia often faces trouble due to the attack of BPH. The rice resistance breeding has become a concern to tackle the BPH infestation in Indonesia. Ministry of Agriculture, Indonesia has been developed and invented some rice cultivars that among them were resistant to BPH. Evaluation of rice resistance is considered important to get information how the adaptation of BPH on the rice cultivars planted by farmers in Indonesia. In this study, we evaluate the rice resistance of some rice cultivars based on the feeding activity of BPH collected from three regencies in Java, i.e. Karawang (West Java), Pekalongan (Central Java) and Kendal (Central Java).

\section{Material and Methods}

The experiments were done in the Laboratory of Entomology, Pest Forecasting Institute (PFI), Ministry of Agriculture, Karawang from April to May 2019. The feeding activity of BPH was assessed by measuring the honeydew excretion and it indicated the rice resistance level $[17,18]$. We conducted honeydew test using a complete random design with eight treatments and five replications based on the method of Heinrich et al. (1985). The colonies of brown planthopper used were collected from rice field on three locations namely Karawang (West Jawa), Pekalongan and Kendal (Central Java). The colonies of brown planthopper were reared in greenhouse using Pelita rice cultivar. The experimental material consisted of eight rice cultivars i.e. Sembada 168, Ciherang, Inpari 32, Inpari 33, IR 64, TN1 (Susceptible check), Ratu Heenati and PTB 33 (Resistance check). For germinating, the seeds of rice were dipped in water for 48 hours. Then, the seeds were sowed on a seedbed for each cultivar. Seven days after planting, the seedlings were removed from seedbed to a pot with a diameter of $8 \mathrm{~cm}$ and a height of $11 \mathrm{~cm}$. We maintained one seedling per cup. The plants were maintained in greenhouse and protected from insects and predators. The plant used for the test were 40 days old. The brown planthoppers were propagated on 40 days old of Pelita rice cultivar (a hopper-susceptible rice cultivar). The brown planthoppers were reared until the $2^{\text {nd }}$ generation. The brown plant hoppers used for the test were gravid females.

There were eight rice cultivars and three brown planthopper populations were used for the honeydew test. Five pots of rice plants in each cultivar were tested for each treatment. Pots that were planted with rice were cover with a transparent plastic cup with a diameter of $7 \mathrm{~cm}$ and a height of 6 $\mathrm{cm}$. A hole was made on the center top of the cup. To avoid escaping BPH, the holes were covered with cotton. The filter paper was dipped in a solution of bromocresol green ( $1 \mathrm{mg}$ bromocresol green and $1 \mathrm{ml}$ ethanol solution) and dried before it was used. The filter paper was placed at the upper side of the cup with a plastic $(10 \mathrm{~cm} \times 10 \mathrm{~cm})$ protecting the filter paper from the humidity of the soil. A number of 200 female adults (five females per plot) were starved for 2 hours before inserting into the pot containing one seedling. Then, the female hoppers were put into the pot containing a rice seedling for 48 hours. The excretion of honeydew dropped on filter paper made spots. The filter papers were put on A4 paper and then, the spots were drawn on a transparent millimeter log using a pencil. The millimeter log containing spots of honeydew excretion was scanned to format JPEG. Then, we measured the area of honeydew spots using "Image J" software.

The area of honeydew spots excreted by brown planthopper was analyzed using ANOVA, MANOVA and cluster analysis with ward method and similarity index of Euclidean distance to group the rice cultivars. Data was analyzed using software PAST 3 [19] . 


\section{Results and Discussion}

\subsection{Results}

\subsubsection{Honeydew spots excreted by BPH feeding on eight rice cultivars}

We conducted evaluation of rice resistance based on the source of the BPH population in Java. The excretion of honeydew dropped by BPH on the filter paper with bromocresol green resulted in spots. One of the methods to evaluate the rice resistance is done by measuring the area of honeydew spots made by the BPH on the filter paper. The spots indicated the amount of solution fed by BPH. The area of honeydew spots was reported to have highly correlated with the amount of honeydew excretion of BPH [20]. The area of honeydew spots were vary according to rice cultivar and population of BPH (Figure 1, 2 and 3). The area of honeydew spots excreted by BPH population of Karawang, West Java from the largest to the smallest were Sembada 168, TN1, Ciherang, Inpari 32, Inpari 33, IR 64, Ratu Heenati and PTB 33, respectively (Figure 4). The area of honeydew spots excreted by BPH population of Pekalongan, Central Java from the largest to the smallest were TN1, Sembada 168, Ciherang, Inpari 32, Inpari 33, IR 64, Ratu Heenati and PTB 33, respectively (Figure 5). However, the area of honeydew spots excreted by BPH population of Kendal, Central Java from the largest to the smallest were Sembada 168, TN1, Ciherang, Inpari 32, IR 64, Inpari 33, Ratu Heenati and PTB 33, respectively (Figure 6).

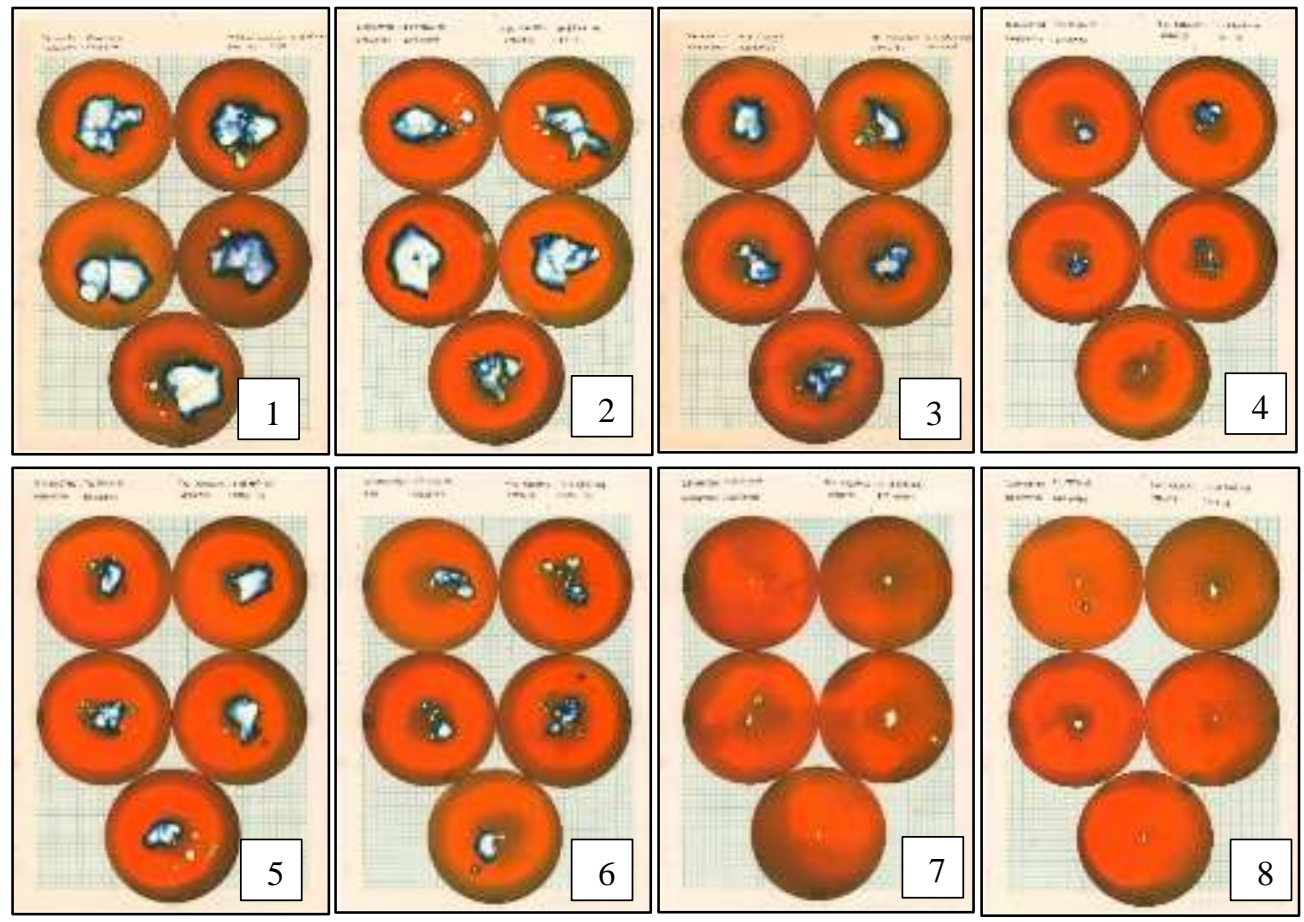

Figure 1

Honeydew spots on bromocresol green paper excreted by BPH population of Karawang on rice cultivars Sembada 168 (1); TN1 (2); Ciherang (3); IR 64 (4); Inpari 32 (5); Inpari 33 (6); Ratu Heenati (7) and PTB 33 (8) 


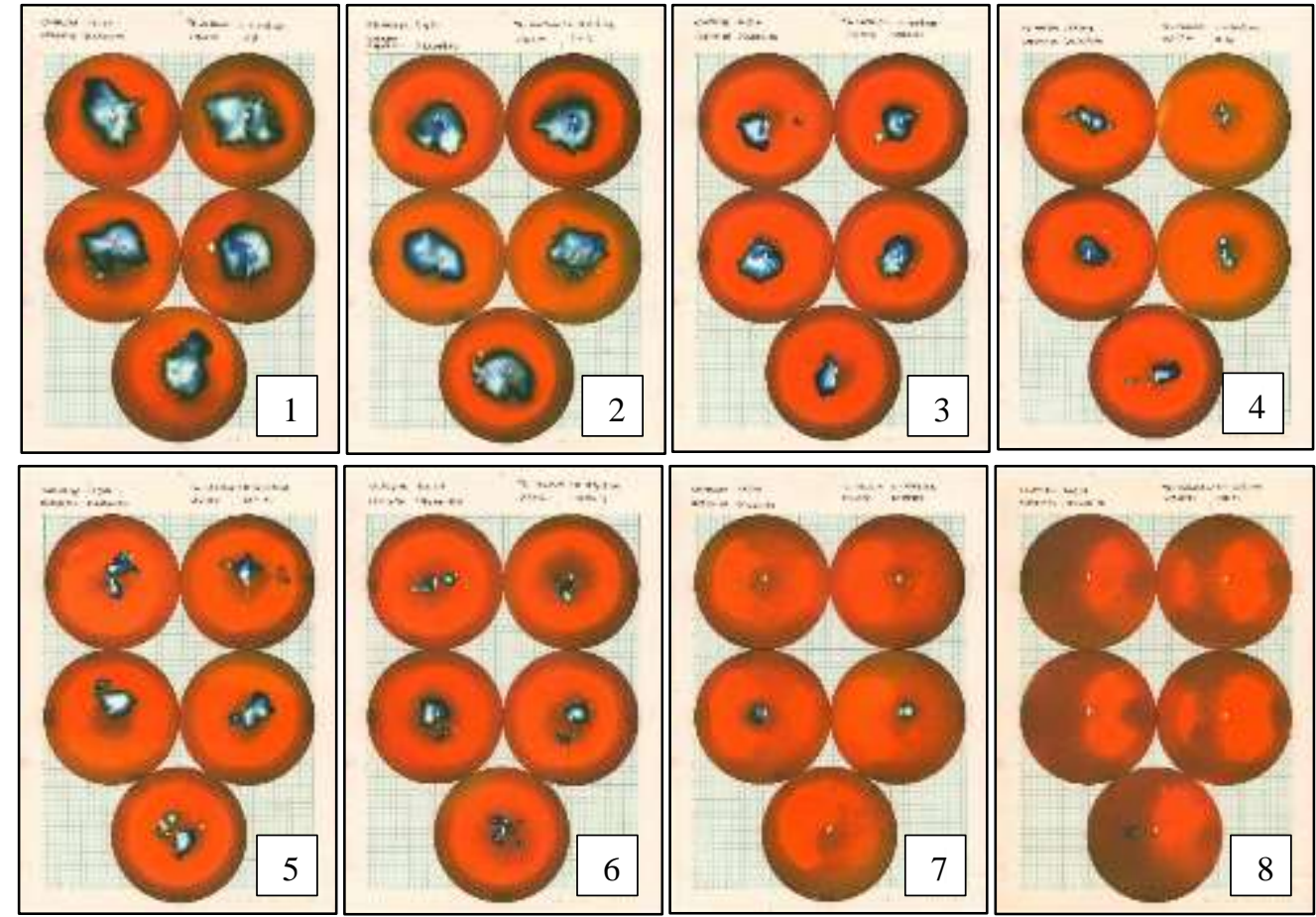

Figure 2

Honeydew spots on bromocresol green paper excreted by BPH population of Pekalongan on rice cultivars Sembada 168 (1); TN1 (2); Ciherang (3); IR 64 (4); Inpari 32 (5); Inpari 33 (6); Ratu Heenati (7) and PTB 33 (8)
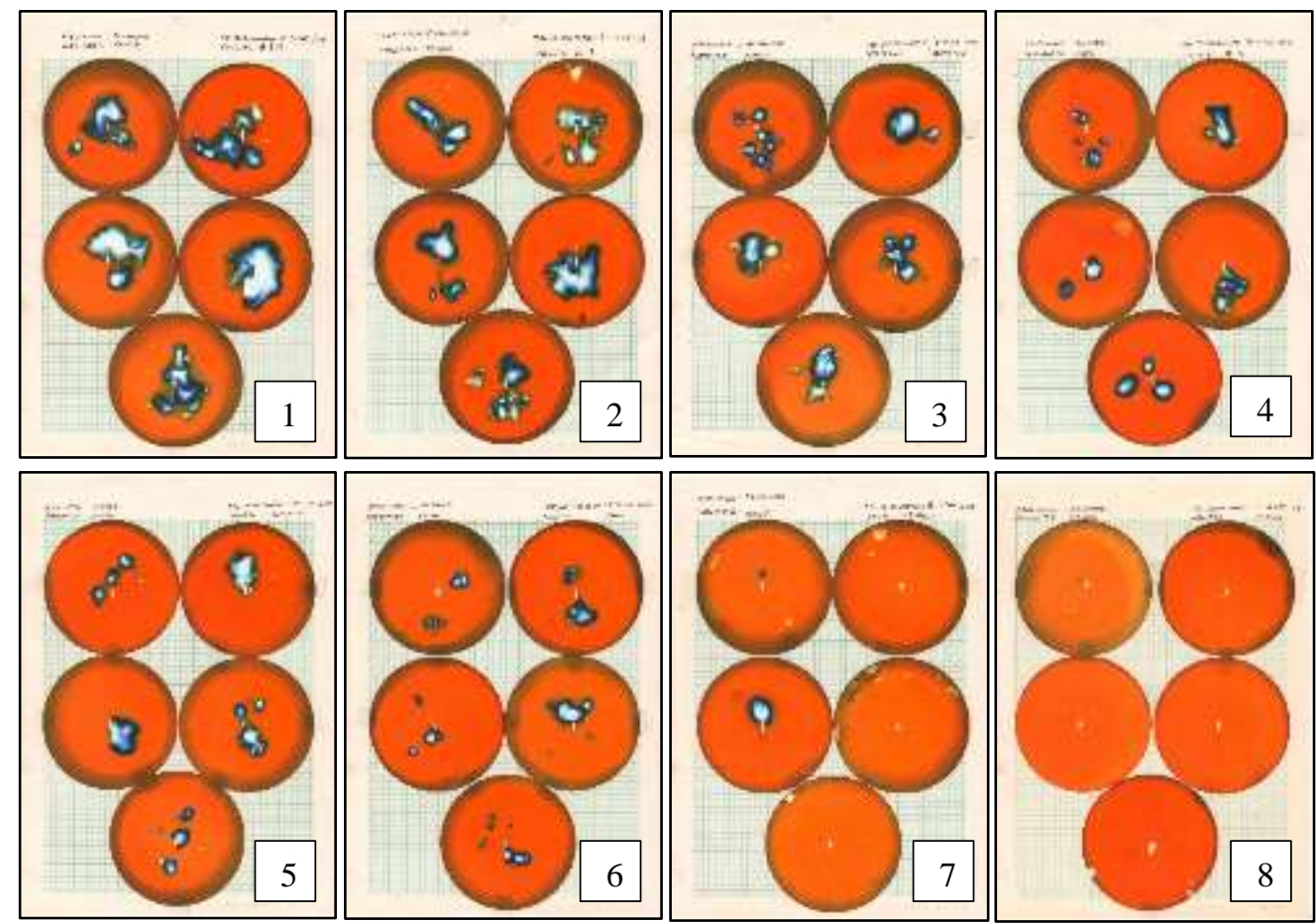

Figure 3

Honeydew spots on bromocresol green paper excreted by BPH's colony of Kendal on rice cultivars Sembada 168 (1); TN1 (2); Ciherang (3); IR 64 (4); Inpari 32 (5); Inpari 33 (6); Ratu Heenati (7) and PTB $33(8)$ 
ANOVA showed significant difference in the area of honeydew spots made by BPH population of Karwang, Pekalongan and Kendal when feeding on the eight rice cultivars $(\mathrm{P}<0.001)$. BPH fed on Sembada 168 excreted the largest honeydew spots compared to other cultivars. However, the smallest area of honeydew spots was found on cultivar PTB 33. There was no significant difference in honeydew spots excreted by BHP population of Pekalongan and Kendal when fed on rice cultivars Sembada 168 and TN1, however there was a significant difference in area of honeydew spots when infested by BPH of Karawang. BPH showed a significant different in area of honeydew spots when fed on the cultivars Ciherang, Inpari 32, Inpari 33 and IR 64, but BPH more preferred Cihereng and Inpari 32 than Inpari 33 and IR 64. Based on the feeding activity of three BPH populations, the cultivars Ratu Heenati and PTB 33 was less preferred by BPH indicated by the smallest honeydew spots.

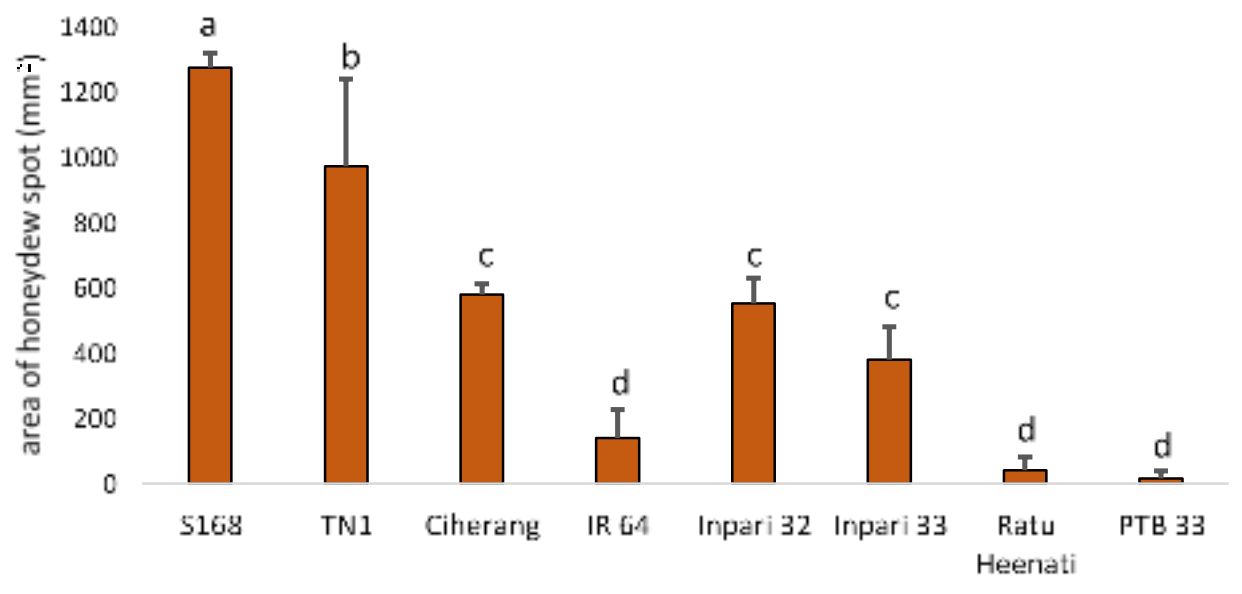

Figure 4

Honeydew spot excreted by brown planthopper population of Karawang, West Java.

Bars exhibited mean \pm standard deviation. Bar with different letter showed significant difference according Tukey test

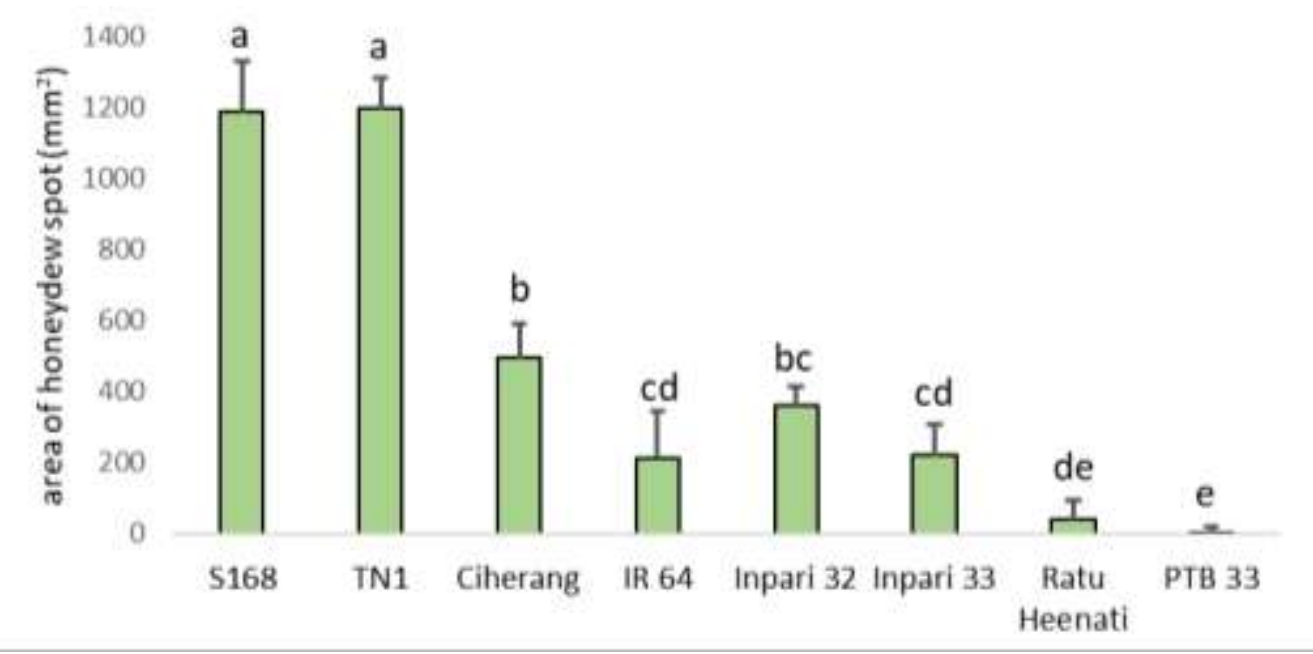

Figure 5

Honeydew spot excreted by brown planthopper population of Pekalongan,

Central Java. Bars exhibited mean \pm standard deviation. Bar with different letter showed significant difference according Tukey test 


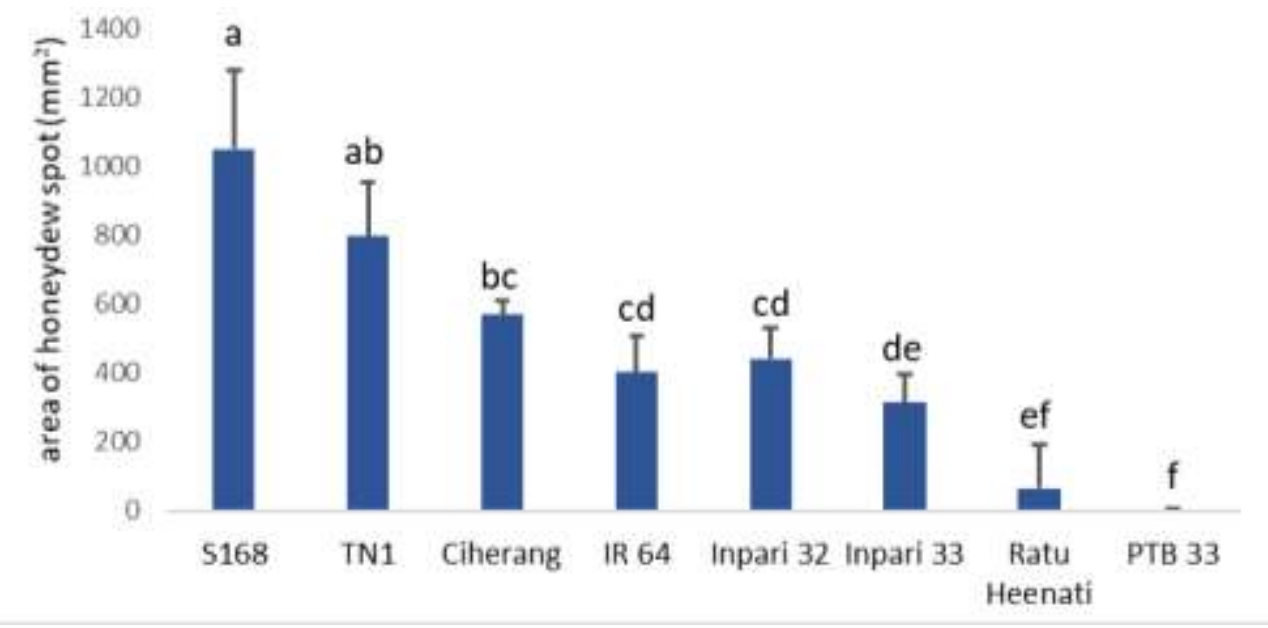

Figure 6

Honeydew spot excreted by brown planthopper population of Kendal, Central Java. Bars exhibited mean \pm standard deviation. Bar with different letter showed significant difference according Tukey test

Multivariate analysis of variance (Manova) showed a significant difference in the area of honeydew spots made by BPH when feeding on the eight rice cultivars (Wilks lambda $=0.005$, $\mathrm{F}=20.95, \mathrm{P}<0.001)$. Pairwise analysis exhibited that area of honeydew spots excreted by BPH were significantly different among the cultivars except the pairwise between cultivar Ciherang and Inpari 32, Inpari 33 and Inpari 32, Ratu Heenati and PTB 33 that showed no significant difference at P>0.05 (Table 1).

Table 1

BPH feeding activity comparison on eight rice cultivars based on multivariate analysis of variance

\begin{tabular}{lccrrrrrr}
\hline Cultivar & S168 & \multicolumn{1}{c}{ TN1 } & Ciherang & \multicolumn{1}{c}{ IR 64 } & Inpari 32 & Inpari 33 & Ratu Henati & PTB-33 \\
\hline Sembada 168 & & 0.042 & 0.000 & 0.000 & 0.000 & 0.000 & 0.000 & 0.000 \\
TN1 & 0.042 & & 0.000 & 0.000 & 0.000 & 0.000 & 0.000 & 0.000 \\
Ciherang & 0.000 & 0.000 & & 0.002 & $0.208^{\mathrm{ns}}$ & 0.010 & 0.000 & 0.000 \\
IR 64 & 0.000 & 0.000 & 0.002 & & 0.005 & 0.041 & 0.022 & 0.010 \\
Inpari 32 & 0.000 & 0.000 & $0.208^{\mathrm{ns}}$ & 0.005 & & $0.089^{\mathrm{ns}}$ & 0.001 & 0.001 \\
Inpari 33 & 0.000 & 0.000 & 0.010 & 0.041 & $0.089^{\mathrm{ns}}$ & & 0.009 & 0.005 \\
Ratu Henati & 0.000 & 0.000 & 0.000 & 0.022 & 0.001 & 0.009 & & $0.853^{\mathrm{ns}}$ \\
PTB-33 & 0.000 & 0.000 & 0.000 & 0.010 & 0.001 & 0.005 & $0.853^{\text {ns }}$ & \\
\hline
\end{tabular}

Value followed by "ns" indicates no significant between two cultivars $(\mathrm{P}>0.05)$

ANOVA and MANOVA clearly showed that BPH of Java have different response to the rice cultivars. The differentiation of feeding activity not only to the rice cultivars but also to the source of BPH population. BPH excreted more honeydew spots indicated the susceptible rice cultivars to the $\mathrm{BPH}$ and the less honeydew spots indicated the resistant rice cultivars.

\subsubsection{Clustering of rice resistance to $\mathrm{BPH}$ population of Java}

The clustering of resistance level to BPH population was evaluated using dendogram with ward method and euclidean similarity index. We used data of honeydew spots area excreted by BPH of Karawang, Pekalongan and Kendal to construct the dendogram. The dendogram showed highly 
cophenetic correlation $(\mathrm{r}=0.88)$. The dendogram exhibited three groups of resistance level i.e. susceptible group (Sembada 168 and TN1), moderately resistant group (Ciherang, IR 64, Inpari 32 and Inpari 33) and strongly resistant group (Ratu Heenati and PTB 33). TN1 is known as the susceptible rice cultivar to BPH in Asia [1,9] and this result showed that TN1 also susceptible to the BPH population in Java. Our study also indicated that Sembada 168 was one group with the susceptible rice cultivar. Cluster analysis showed that 4 of eight rice cultivars tested were grouped as moderately resistant. There were two sub groups on the moderately resistant namely Ciherang and Inpari 32 as one sub group and IR 64 and Inpari 33 as another sub group. The dendogram showed that Ciherang and Inpari 32 were closer to the susceptible group, however the IR 64 and Inpari 33 were closer to the strongly resistant group.

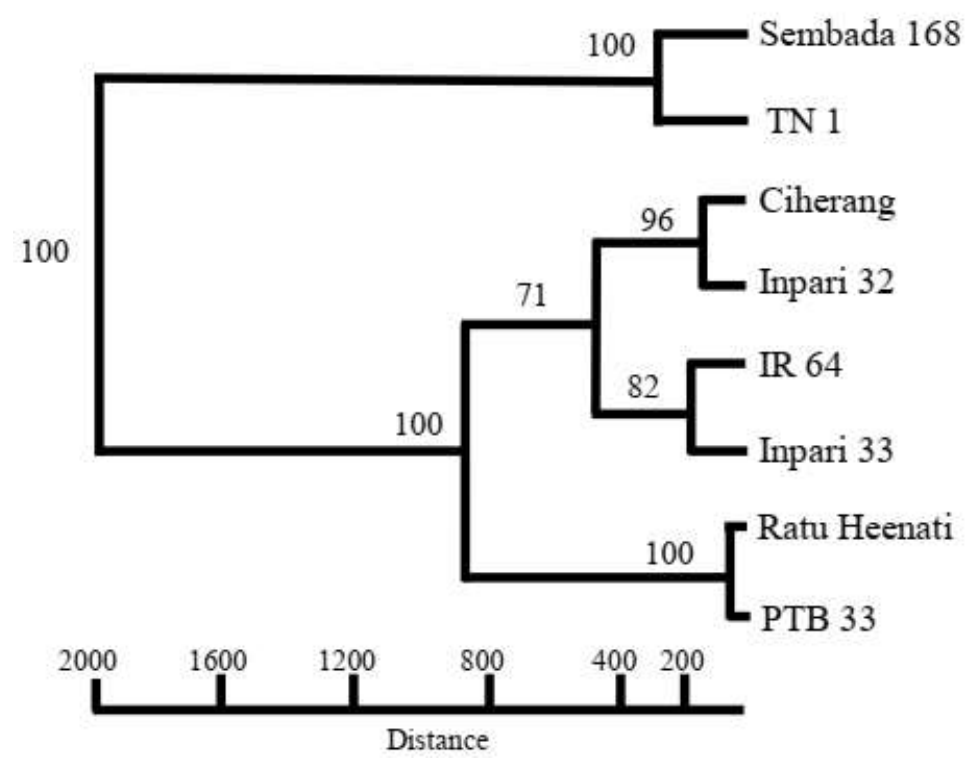

Figure 7

Resistance clustering of eight rice cultivars based on feeding activity of BPH of Karawang,

Pekalongan and Kendal using ward method and euclidean similarity index

(Cophenetic correlation $=0.88$, boot $\mathrm{N}=1000)$.

\subsection{Discussion}

Evaluation of rice resistance through analysis of honeydew excreted by BPH is widely used as one of methods to assess rice resistance to BPH [8]. Developing of rice resistance cultivar is one of the effective methods in integrated pest management and this technique have no effect to the non target insect [11]. In this test, we evaluated eight rice cultivars by infesting three BPH populations in Java. This study showed that the source of BPH population and kind of rice cultivar affected the activity of feeding the BPH. Therefore, the area of honeydew spots resulted from BPH were vary among the rice cultivars. The largest area of honeydew spots indicated the highly resistant rice cultivars, while the smallest area of honeydew spots indicated the susceptible cultivars. The clustering analysis clearly exhibited three groups of resistant level namely susceptible, moderately resistant and strongly resistant. The cultivars Sembada 168 and TN1 were grouped as susceptible to the three BPH populations in Java. The rice cultivars Ciherang, Inpari 32, Inpari 33 and IR 64 were grouped as moderately resistant and Ratu Heenati and PTB 33 were grouped as strongly resistant to BPH populations of Java. TN1 known as the susceptible rice cultivar to BPH in Asia and high fecundity of BPH was recorded on TN1 [10, 20]. Baehaki and Munawar (2013) reported that TN1 
was susceptible to BPH biotype 3 in Indonesia [21]. The cultivar Sembada 168 that was one grouped with TN1, should be avoid to planted in Java due to its susceptibility to BPH.

The response of BPH feeding on rice was different on each rice cultivar. BPH spends a long time to feed the rice with is identified as a susceptible cultivar [22]. Otherwise, the BPH spends a short time for settling and feeding on the strongly resistant rice cultivars [20]. Ability of BHP to establish its population depends on the kind of rice cultivar. The characteristic of biophysical and biochemical effects the insect to establish its population [23]. The study showed that the BPH population of Karawang excreted more honeydew when fed on Sembada 168 than TN1 and Tukey test showed significantly different $(\mathrm{P}<0.05)$. It indicated that Sembada 168 was more susceptible to the BPH population of Karawang than to TN1. The cultivars Ciherang and Inpari 32 were more preferred by the BPH population of Java than IR 64 and Inpari 33 even though those cultivars were clustered as moderate resistant. The dendogram clearly exhibited that resistance level of Ciherang was similar to Inpari 32 and IR 64 was similar to Inpari 33. The cultivars Ciherang, Inpari 32, IR 64 and Inpari 33 were commonly planted by farmers in Java. Our result indicated that Ciherang and Inpari 32 were close to susceptible cultivars (TN1). We recorded that cultivar Inpari 32 and Ciherang were attacked by BPH in Java and caused hopper burn on some rice field in Java in 2019 (unpublish data). We recommend to avoid planting the susceptible cultivars (Sembada 168) and some moderate resistant cultivars such as Inpari 32 and Ciherang that were closer to susceptible against BPH in Java. The study for improvement of rice cultivar with resistance gene to BPH has been researching and developing especially in rice producer countries in Asia [24-27]. Due to the BPH ability and good adaption to its host plant, we suggested inventing a resistant rice cultivar as one of strategy to control the BPH in Indonesia.

\section{Conclusion}

The feeding activity of BPH was affected by the source of the BPH population and rice cultivar. Evaluation of rice resistance based on feeding activity of BPH showed that cultivars Sembada 168 and TN1 were grouped as susceptible, cultivars Ciherang, Inpari 32, Inpari 33 and IR 64 were moderately resistant and cultivars Ratu Heenati and PTB 33 were strongly resistant to BPH populations in Java.

\section{Acknowledgements}

We would like to thank the head of Pest Forecasting Institute (PFI), Ministry of Agriculture who have supported us during the research and all staff in the laboratory of entomology that helped in the preparation of the materials for this research.

\section{References}

[1] Khush, G. (1979). Genetics of resistance and breeding for resistance to the brown planthopper. In IRRI (Ed.), Brown planthopper: threat to rice production in Asia. Los Baños, Philippines: 321-332.

[2] Sogawa, K., G. Liu, and J. Shen. (2003). A review on the hyper-susceptibility of Chinese hybrid rice to insect pests. Chinese Journal of Rice Science, 17, 23-30.

[3] Sogawa, K. (1982). The rice brown planthopper: feeding physiology and host plant interactions. Annual Review of Entomology, 27, 49-73.

[4] Rivera, C., S. Ou, and T. Lida. (1966). Grassy stunt disease of rice and its transmission by Nilaparvata lugens (Stal). Plant Disease Reporter, 50(7), 453-456.

[5] Cabauatan, P., R. Cabunagan, and I.-R. Choi. (2009). Rice viruses transmitted by the brown planthopper Nilaparvata lugens Stål. In K. Heong and B. Hardy (Eds.), Planthoppers: new threats to the sustainability of intensive rice production systems in Asia. Los Banos: International Rice Research Institute. 
[6] Sogawa, K. and C. Cheng. (1979). Economic thresholds, nature damage, and losses caused by the brown planthopper In I. R. R. Institute (Ed.), Brown planthopper: threat to rice production in Asia (pp. 125-142). Los Baños, Philippines: IRRI.

[7] Heinrich, E., F. Medrano, and H. Rapusas. (1985). Genetic Evaluation for Insect Resistance in Rice. Los Banos, Philippines: IRRI.

[8] Choi, S. (1979). Screening method and sources of varietal resistance. In I. R. R. Institute (Ed.), Brown planthopper: threat to rice production in Asia (pp. 171-186). Los Baños, Philippines IRRI.

[9] Gaffar, M., J. Pritchard, and B. Ford-Llyoid. (2011). Brown Planthopper (N. lugens Stal): Feeding behaviour on rice germplasm as an indicator of resistance. PLOS ONE, 6(7), e22137. doi:10.1371/journal.pone.0022137.

[10] Harini, S., S. Kumar, P. Balaravi, R. Shrama, A. Dass, and V. Shenoy. ( 2013). Evaluation of rice genotypes for brown planthopper (BPH) resistance using molecular markers and phenotypic methods. African Journal of Biotechnology, 12(19), 2515-2525.

[11] Sarao, P. and J. Bentur. (2016). Antixenosis and tolerance of rice genotypes against brown planthopper. Rice Science, 23(2), 96-103.

[12] Athwal, D., M. Pathak, E. Bacalangco, and C. Pura. (1971). Genetics of resistance to brown planthoppers and green leaf hoppers in Oryza sativa. L Crop Science 11, 747-750.

[13] Lakshminarayana, A. and G. Khush. (1977 ). New genes for resistance to the brown planthoppers. Crop Science 17, 96-100.

[14] Tanaka, K. and M. Matsumura. (2000). Development of virulence to resistant rice varieties in the brown planthopper, Nilaparvata lugens (Homoptera: Delphacidae), immigrating into Japan. Applied Entomology and Zoology, 35, 529-533.

[15] Myint, K., H. Yasui, M. Takagi, and M. Matsumura. (2009). Virulence of long-term laboratory populations of the brown planthopper, Nilaparvata lugens (Stål), and whitebacked planthopper, Sogatella furcifera (Horváth) (Homoptera: Delphacidae), on rice differential varieties. Applied Entomology and Zoology, 44, 149-153.

[16] Horgan, F., A. Ramal, J. Bentur, R. Kumar, B. Vasanta, P. Sarao, E. Iswanto, H. Chien, M. Phyu, C. Bernal, M. Almazan, M. Alam, Z. Lu, and S. Huang. (2015). Virulence of brown planthopper (Nilaparvata lugens) populations from South and South East Asia against resistant rice varieties. Crop Protection, 78, 222-231.

[17] Auclair, J. (1959). Feeding and excretion by the pea aphid Acyrthosiphon pisum (Harr.) (Homoptera: Aphididae) reared on different varieties of peas. Entomologia Experimentalist et Applicata, 2, 279286.

[18] Liu, G., R. Saxena, and R. Wilkins. (1994). Behavioral responses of the white-backed planthopper, Sogatella furcifera (Homoptera: Delphacidae) on rice plants whose odors have been masked. Journal of Insect Behavior, 7(343-353).

[19] Hummer, Ø., D. Harper, and P. Ryan. (2001). Paleontological statistics software package for education and data analysis. Paleontologia Electronica, 4(1), 9.

[20] Senguttuvan, T., M. Gopalan, and S. Chelliah. (1991). Impact of resistance mechanisms in rice against brown planthopper, Nilaparvata lugens Stal (Homopetera: Delphacidae). Crop Protection, 2, 125128.

[21] Baehaki, S. and D. Munawar. (2013). Resistance test of rice lines againts brown planthopper biotype 3 through population build-up. Jurnal Entomologi Indonesia, 10(1), 7-17.

[22] Brar, D., P. Virk, K. Jena, and G. Khush. (2009). Breeding for resistance to planthoppers in rice. In K. Heong and B. Hardy (Eds.), Planthoppers: new threats to the sustainability of intensive rice production systems in Asia (pp. 401-428). Los Baños, Philippines: IRRI.

[23] Saxena, R. and M. Pathak. (1979). Factor governing susceptibility and resistance of certain rice varieties to the brown planthopper. In I. R. R. Institute (Ed.), Brown planthopper: threat to rice production in Asia (pp. 303-317). Los Baños, Philippines: IRRI.

[24] Haliru, B., M. Rafii, N. Mazlan, S. Ramlee, I. Muhammad, I. Akos, J. Halidu, S. Swaray, and Y. Bashir. (2020). Recent Strategies for Detection and Improvement of Brown Planthopper Resistance Genes in Rice: A Review. Plants, 9(1202), 1-19.

[25] Park, J., S. Yun, R. Jan, and K. Kim. (2020). Screening and Identification of Brown Planthopper Resistance Genes OsCM9 in Rice. Agronomy, 10(1865), 1-13.

[26] Huang, Z., G. He, L. Shu, X. Li, and Q. Zang. (2001). Identification and mapping of two brown planthopper resistance genes in rice. Theoretical and Applied Genetics, 102, 929-934.

[27] Deen, R., K. Ramesh, G. Padmavathi, B. Viraktamath, and T. Ram. (2017). Mapping of brown planthopper [Nilaparvata lugens $\left(\mathrm{Sta}^{\circ} \mathrm{l}\right)$ ] resistance gene (bph5) in rice (Oryza sativa $\left.\mathrm{L}.\right)$. Euphytica 213(35), 1-14. 